\title{
Structural and functional relationship of mammalian and nematode ferritins
}

\author{
JarosŁaW LeWandowski ${ }^{\# *}$, Alicja A. KomUR ${ }^{\#}$, Daria SobańSKa ${ }^{\#}$ \\ Institute of Bioorganic Chemistry, Polish Academy of Sciences, Poznań, Poland \\ ${ }^{\#}$ All authors contributed equally to this work
}

\begin{abstract}
Ferritin is a unique buffering protein in iron metabolism. By storing or releasing iron in a tightly controlled manner, it prevents the negative effects of free ferrous ions on biomolecules in all domains of life - from bacteria to mammals. This review focuses on the structural features and activity of the ferritin protein family with an emphasis on nematode ferritins and the similarities in their biological roles with mammalian ferritins. The conservative characteristic of the ferritin family across the species originates from the ferroxidase activity against redox-active iron. The antioxidative function of these proteins translates into their involvement in a wide range of important biological processes, e.g., aging, fat metabolism, immunity, anticancer activity, and antipathogenic activity. Moreover, disturbances in ferritin expression lead to severe iron-associated diseases. Research on the Caenorhabditis elegans model organism may allow us to better understand the wide spectrum of mechanisms involving ferritin activity.
\end{abstract}

Key words: ferritin, ferroxidase activity, iron metabolism, reactive oxygen species, iron storage

\section{Introduction}

Ferritin was first identified by Laufberger in 1937 (Laufberger, 1937) who isolated the protein from the horse spleen, crystallized it, and coined the term "ferritin" from the Latin word ferratus, which means furnished, covered, or shod with iron. To date, the ferritin superfamily is one of the most studied protein superfamilies because of its importance as a clinical biomarker for inflammation, infection, and malignancy. The quantity of serum ferritin serves as an indicator of the body's iron store (Daru et al., 2017). Iron deficiency is associated with anemia, whereas an elevated iron level indicates the possibility of many severe disorders such as iron overload diseases and hemochromatosis (Allen et al., 2008); chronic and acute inflammation (WesslingResnick, 2010); and cancer development, e.g., neuroblastoma (Mura et al., 2006), hepatocellular carcinoma (Tang et al., 2020), or Hodgkin's lymphoma (Hohaus et al., 2013) (presumably due to the occurrence of inflammation (Alkhateeb and Connor, 2013)). Studies on mice showed the importance of ferritin heavy chain (FTH1) for proper embryonic development, as its deletion was found to be lethal (Ferreira et al., 2000). Moreover, FTH1-null mice showed elevated oxidative stress and higher apoptosis rate (Thompson et al., 2003). Thus, understanding how ferritin works is crucial for the development of new therapies for diseases related to ferritin dysregulation. Because of the high similarity of nematode ferritins to human FTH1, Caenorhabditis elegans can serve as a model organism to study ferritin-mediated biological processes.

\section{Expression of ferritins}

The ferritin superfamily includes not only vertebrate ferritin but also bacterial ferritin and bacterioferritin (Yevenes, 2017), DNA protection during starvation protein (Dps) and Dps-like proteins (Calhoun and Kwon, 2011; Haikarainen and Papageorgiou, 2010; Wiedenheft et al., 2005), and archaeoferritin (Ebrahimi et al., 2012). Ferritin is a highly conserved (Fig. 1) ubiquitous protein

\footnotetext{
* Corresponding author: Institute of Bioorganic Chemistry, Polish Academy of Sciences, Poznań, Poland; e-mail: jarekl@man.poznan.pl
} 


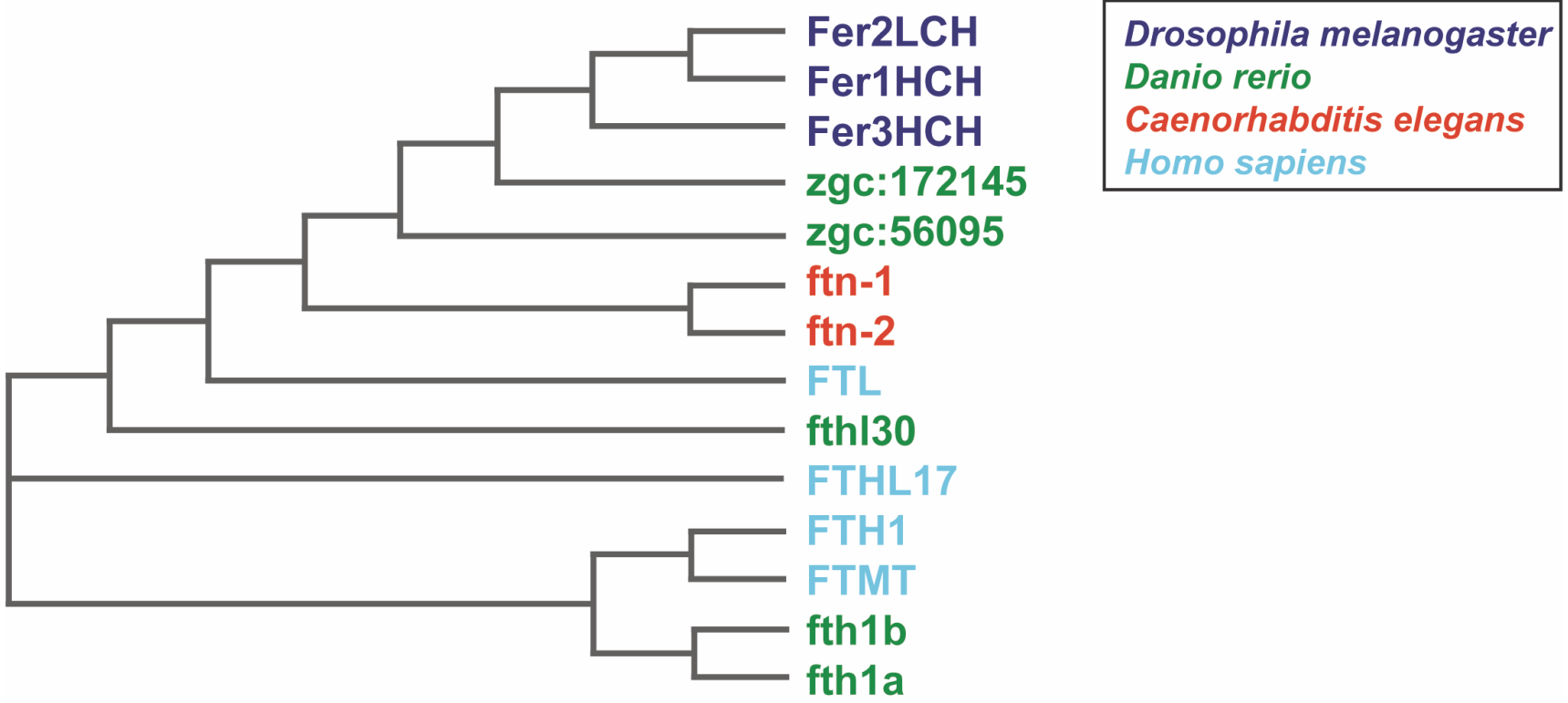

Fig. 1. Phylogenetic relationship of ferritins from Caenorhabditis elegans, Drosophila melanogaster, Danio rerio, and Homo sapiens. The phylogenetic tree was computed using the multiple sequence alignment program ClustalOmega (http://www.ebi.ac.uk/ Tools/msa/clustalo/) (Sievers et al., 2011) and drawn using the ClustalW2 program (http://www.ebi.ac.uk/Tools/msa/clustalw2) (Larkin et al., 2007)

that has been identified in many species from all domains of life, with one known exception - it is not found in yeasts (de Llanos et al., 2016). C. elegans expresses two ferritins, namely FTN-1 and FTN-2, which share higher sequence similarity with the mammalianFTH (Fig.2) than with the mammalian ferritin light chain (FTL) (Gourley et al., 2003). Mammalian ferritin is mostly expressed as a cytosolic protein; however, it has also been detected in mitochondria (Levi et al., 2021) and nucleus (Alkhateeb and Connor, 2010) and as an extracellular protein in serum (Knovich et al., 2009) and cerebrospinal fluid (Ayton et al., 2015). In contrast, the expression of FTN-1 and FTN-2 in C. elegans is induced by high iron level in the intestine, while FTN-2 is also expressed constitutively (Cha'on et al., 2007; Kim et al., 2004).

Iron regulates ferritin expression at the transcriptional and post-transcriptional levels (Hintze and Theil, 2006; Romney et al., 2011). The expression of most eukaryotic ferritins is regulated by iron-responsive elements (IRE) located in 5'-UTRs of mRNAs. These sequences are specifically bound by iron-regulatory proteins 1 and 2 (IRP-1/2) (Zhou and Tan, 2017). The multiple functions of ferritin are evident by the binding of numerous transcription factors to the Fth 1 gene promoter, e.g., activator protein 1 (AP-1 - involved in the regulation of cell growth, differentiation, and apoptosis),
GATA-binding factor 1 (GATA-1 - involved in erythroid development), growth factor independent 1 transcriptional repressor (GFI1 - activated in hematopoiesis and oncogenesis), and HSF2 (promoting the expression of heat shock response genes) (based on www.genecards.org). Mutations (e.g., deletions and single nucleotide polymorphisms (SNPs)) in 5'-UTR regions that disrupt the protein-promoter interactions in the IRE sites lead to the dysregulation of serum ferritin levels and the development of the hereditary hyperferritinemia cataract syndrome (Celma Nos et al., 2021). Recently, the regulation of ferritin chain translation independent of IRP-IRE has also been reported. Pulos-Holmes et al. (2019) revealed that human eukaryotic translation initiation factor 3 (eIF3) functions as a repressor of human FTL translation by binding to the sequences in the 5 '-UTR adjacent to the IRE fragments (Pulos-Holmes et al., 2019).

In contrast, the expression of FTN-1 and FTN-2 genes in $C$. elegans is regulated at the transcriptional level through iron-dependent enhancers (IDEs) located in their promoters (Romney et al., 2008). Constitutive expression of $f t n-1$ and $f t n-2$ is induced by the intestinal GATA transcription factor, erythroid-like transcription factor (ELT-2), that interacts with the GATA sequences in ferritin IDEs (Anderson and Leibold, 2014). Additio- 


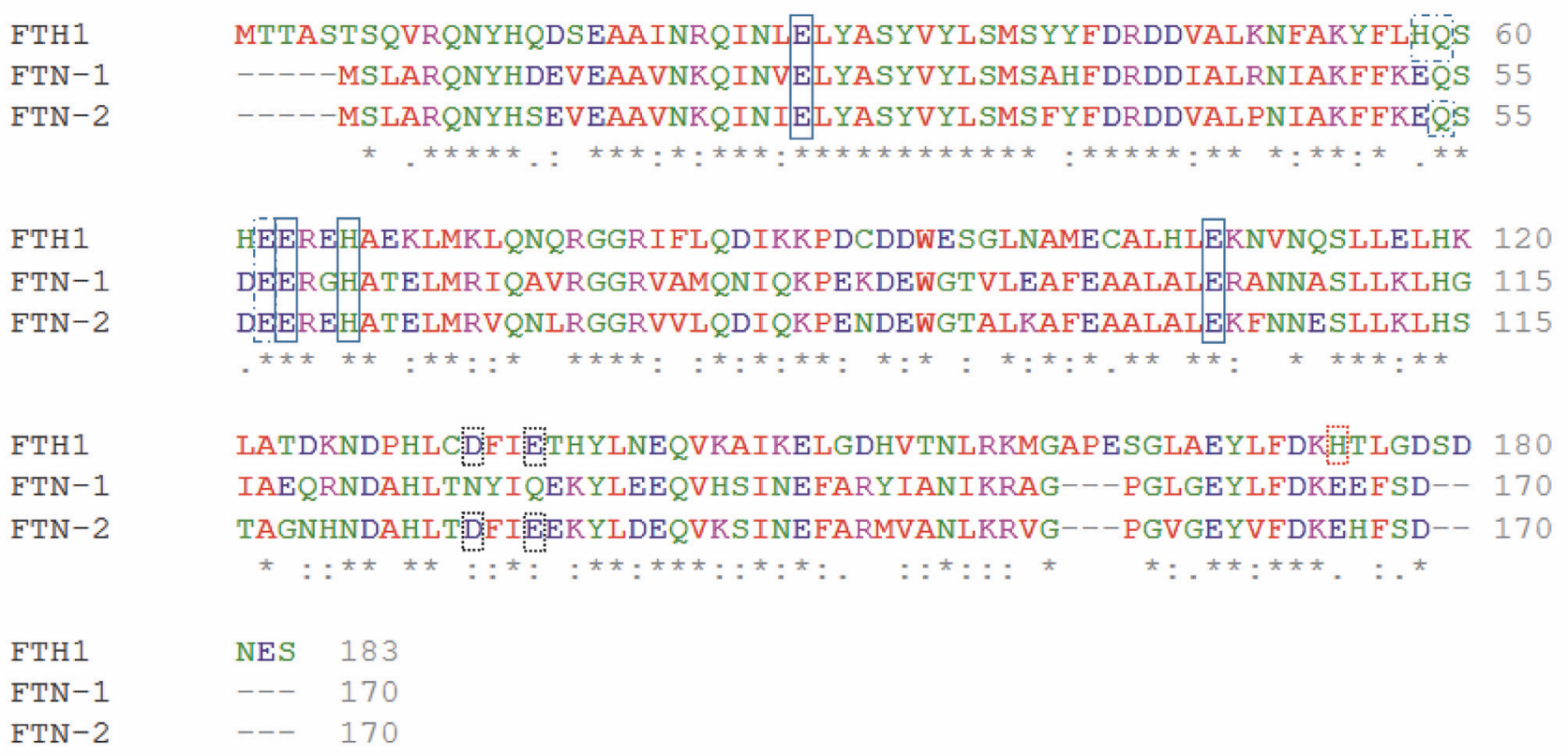

Fig. 2. Amino acid sequence alignment of Homo sapiens ferritin heavy chain 1 FTH1 and Caenorhabditis elegans ferritins FTN-1 and FTN-2. The alignment was achieved using the multiple sequence alignment software ClustalOmega (http://www.ebi.ac.uk/ Tools/msa/clustalo/) (Sievers et al., 2011). Amino acid sequences were obtained from the NCBI database (H. sapiens FTH1 NP_002023.2, C. elegans FTN-1 NP_504944.2, and C. elegans FTN-2 NP_491198.1). A single, fully conserved residue is marked by an asterisk $\left({ }^{*}\right)$, residues with strongly similar properties are represented by a colon (:), and groups of residues with weakly similar properties are shown by a period (.). Solid-line boxes indicate residues being ligands for iron ions; the dashed-line boxes show amino acid residues playing a role in the oxidoreductase activity as additional binding sites; and the black and red dotted-line boxes respectively show amino acids interacting with $\mathrm{Fe}$-aquaions or Fe binding observed in the spatial structures. The indication of amino acid residues is made based on Pozzi et al. (2015)

nally, nematode ferritin genes are repressed by the binding of hypoxia-inducible factor-1 (HIF-1) to the IDE upon iron deficiency (Romney et al., 2011). Moreover, ftn-1 is regulated by abnormal dauer formation (DAF-16) transcription factor under nutrient deprivation (Ackerman and Gems, 2012).

\section{Structure of ferritins}

The tertiary structures of different ferritins are mostly conserved, forming a spherical protein of molecular weight of $480 \mathrm{kDa}$ with an outer diameter of approximately $12 \mathrm{~nm}$ and an inner cavity of $8 \mathrm{~nm}$. The two subunits, namely FTH (formed by 183 amino acids) and FTL (formed by 175 amino acids), are approximately 21 and $19 \mathrm{kDa}$ in size, respectively. Each subunit is folded into a four-helix bundle of similar length, with a long loop between helices $\mathrm{B}$ and $\mathrm{C}$, and a fifth short C-terminal helix E (Chakraborti and Chakrabarti, 2019) (Fig. 3). Classical ferritins consist of 24 subunits; however, larger (36 subunits - found in the heart and skeletal muscles) and smaller forms (12 subunits - mini-ferritin found in bacteria) have also been identified (Bradley et al., 2020; Zhang et al. 2021). Interestingly, ferritins are capable of self-assembly into a 24-mer shell, both in vivo and in vitro (Chakraborti and Chakrabarti, 2019). The protein shell of mammalian ferritin is usually heterogeneous and is constituted either from FTH or FTL or from both. In mammals, $\mathrm{H}$ and $\mathrm{L}$ subunits exhibit around $50 \%$ amino acid sequence similarity, and the FTH/FTL ratio varies in different tissues from the same organism depending on the relative expression of the two genes (Laghaei et al., 2014; Naumova et al., 2014). In contrast, plant and bacterial ferritins are homopolymers and resemble mammalian FTH (Masuda et al., 2007).

\section{Iron loading and ferroxidase activity}

A single ferritin molecule can hold between a few hundred to up to 4500-5000 iron ions (Jian et al., 2016). The two ferritin subunits have distinct functions in maintaining iron homeostasis: the $\mathrm{L}$ subunit uses its multimer core for iron storage and mineralization (BouAbdallah et al., 2008; Melman and Bou-Abdallah, 2020), 


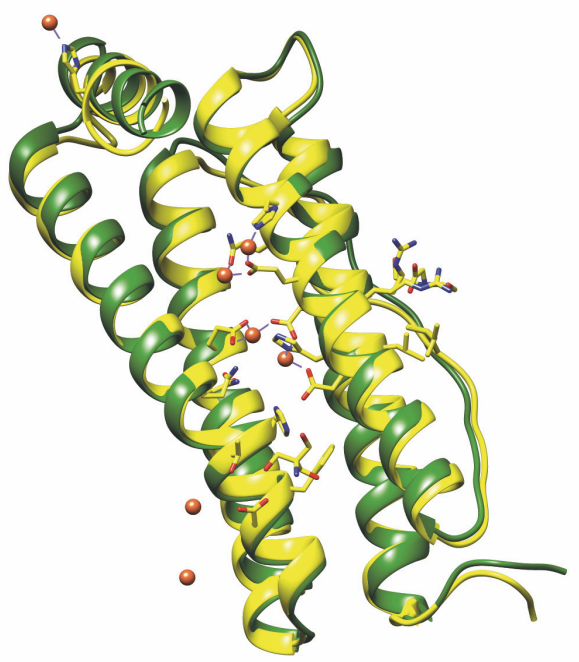

Fig. 3. Structural alignment of Caenorhabditis elegans ferritin FTN-1 (green) and Homo sapiens ferritin heavy chain 1 FTH1 (yellow, PDB ID 4OYN). The structure prediction of FTN-1 was achieved by the Phyre2 tool (Kelley et al., 2015). Amino acid residues essential for reactivity with iron are shown with sticks and balls and belong to FTH1. The colors are represented as follows: oxygen atoms (red), nitrogen atoms (dark blue), carbon atoms (FTH1 - yellow; FTN-1 - green), iron atoms (dark orange balls), and coordination bonds (purple lines)

while the $\mathrm{H}$ subunit harbors ferroxidase activity facilitated by the dinuclear iron-binding site (Zarjou et al., 2010). The ferroxidase site oxidizes $\mathrm{Fe}^{2+}$ to $\mathrm{Fe}^{3+}$ by molecular oxygen $\left(\mathrm{O}_{2}\right)$ or hydrogen peroxide $\left(\mathrm{H}_{2} \mathrm{O}_{2}\right)$ (Zhao et al., 2003). $\mathrm{Fe}^{3+}$ is displaced by another $\mathrm{Fe}^{2+}$ ion and then rapidly transferred into the nucleation sites on the L subunit (Honarmand Ebrahimi et al., 2012). Synergistic action between $\mathrm{H}$ and $\mathrm{L}$ subunits allows the $\mathrm{H}$ subunit to rapidly oxidize $\mathrm{Fe}^{2+}$ to $\mathrm{Fe}^{3+}$, while the $\mathrm{L}$ subunit releases oxidized iron and stores it (Bou-Abdallah et al., 2008). Depending on iron loading and molecular environment, when not required immediately in biological processes, oxidized iron is stored as ferritin-oxide minerals, such as magnetite $\left(\mathrm{Fe}_{3} \mathrm{O}_{4}\right)$, ferrihydrite $\left(5 \mathrm{Fe}_{2} \mathrm{O}_{3} \cdot 9 \mathrm{H}_{2} \mathrm{O}\right)$, maghemite $\left(\gamma-\mathrm{Fe}_{2} \mathrm{O}_{3}\right)$, or hematite $\left(\alpha-\mathrm{Fe}_{2} \mathrm{O}_{3}\right)$ (Cowley et al., 2000; Svobodova et al., 2020). In contrast, under physiological conditions, iron is released from ferritin when iron concentration in the cytosol decreases either due to being exported during cell metabolism in the process of ferritin degradation called ferritinophagy or in response to iron sequestration by the overexpression of the other iron-binding protein -ferroportin (Vela, 2020). Studies on bactoferritin showed that a heme group, which is not present in other ferritins, plays an im- portant role in iron release from ferritin mineral, while the ferroxidase center is not involved in that process (Yasmin et al., 2011). However, the molecular mechanism of iron release from mammalian ferritin without damage of the protein is yet to be determined. Because of the diverse roles of the $\mathrm{L}$ and $\mathrm{H}$ subunits in iron homeostasis, the composition of ferritin molecules differs in each organ, depending on its role in iron metabolism. For example, in the liver and spleen, they are involved in iron storage and show high levels of the $\mathrm{L}$ subunit (Ahmad et al., 2013), while in heart tissues, they contain increased levels of the $\mathrm{H}$ subunit (Knovich et al., 2009). Interestingly, despite the fact that both $C$. elegans ferritins - FTN-1 and FTN-2 - harbor ferroxidase center that is conserved to FTH1 (Fig. 2 and Fig. 3) (Gourley et al., 2003), they seem to exert diverse functions as only FTN-2 contributes to iron storage (James et al., 2015).

Despite the high conservation of the structure of ferritins, the amino acid sequence composition of the ferroxidase center is different, except for the conserved residues located in the ferroxidase center (Andrews, 2010; Bradley et al., 2014). Human FTH, bacterial ferritins, and bacterioferritin contain a highly conserved ferroxidase center with two iron-binding sites ( $\mathrm{A}$ and $\mathrm{B}$ ). Interestingly, some archaeal and bacterial ferritins and bacterioferritin possess a third iron-binding site (site $\mathrm{C}$ ) of unknown function in the close proximity to the ferroxidase center (Bou-Abdallah et al., 2014).

\section{Biological roles of ferritins}

Ferritin controls iron homeostasis through the regulation of iron pool availability (Muhoberac and Vidal, 2019). Consequently, iron homeostasis is crucial for protection against DNA and protein damages that lead to cell injury and death. Importantly, many hematologic (e.g., anemia, HFE-associated hereditary hemochromatosis like thalassemia, congenital sideroblastic anemias), metabolic (e.g., diabetes), and neurodegenerative disorders (e.g., aceruloplasminemia, Friedrich's ataxia, Parkinson's disease, and Alzheimer's disease) are associated with iron overload or deficiency (Anderson and Leibold, 2014; Dev and Babitt, 2017). C. elegans expresses a large group of highly conserved proteins (e.g., ferroportins - FPN-1.1, FPN-1.2, and FPN-1.3; ferritins - FTN-1 and FTN-2) involved in iron metabolism that 
makes it a relevant model organism to study molecular mechanisms of iron homeostasis control (Anderson and Leibold, 2014). Below, we describe the biological roles of ferritins that are common for nematodes and mammals to emphasize the potential of $C$. elegans in studying mechanisms underlying iron homeostasis.

\section{Ferritin as an antioxidant}

Iron is necessary for the production of ATP in the mitochondria, for the synthesis and function of heme proteins of the respiratory chain, and for DNA synthesis (Gao et al., 2021). Additionally, iron is essential for several core processes occurring in the brain, such as the synthesis of myelin and neurotransmitters and as a cofactor of related pivotal enzymes, e.g., tyrosine hydroxylase involved in the synthesis of dopamine and other catecholamines, tryptophan hydroxylase necessary for serotonin production, and monoamine oxidase (Crichton et al., 2011). However, the imbalance of iron level can activate the formation of reactive oxygen species (ROS) and lead to cell injury and death (He et al., 2017). In this section, we discuss the relationship between ferritin function and ROS generation in maintaining organism homeostasis based on studies in nematodes (C. elegans) and mammals.

Antioxidants are known to protect living cells from harmful effects of ROS (He et al., 2017). The protective effect of ferritin under hypoxic stress conditions was confirmed in human leukemia (Wang et al., 2019), porcine aortic endothelial (Balla et al., 2003), hypoxia-induced brain damage (Wu et al., 2019), and HeLa cells (Orino et al., 2001). FTH was reported to be critical for antioxidative protection (Chiou and Connor, 2018). As an example, overexpression of FTH protected HeLa cells from apoptosis generated by tumor necrosis factor $\alpha$ (TNF- $\alpha)$ (Cozzi et al., 2003) and transforming growth factor $\beta 1$ (TGF- $\beta 1$ )-driven ROS release (Zhang et al., 2009), and protected MCF-7 breast cancer cells from cytotoxicity generated by oxidative stress (Buranrat and Connor, 2015).

The relationship between ferritin-dependent iron metabolism and $\mathrm{O}_{2}$ metabolism has been poorly studied. However, there is some evidence indicating the functional relationship between these processes in $C$. elegans, e.g., $f t n-1$ gene expression is responsive to changeable oxygen conditions and is significantly upregulated following exposure to $1 \% \mathrm{O}_{2}$ (hypoxia) (Romero-Afrima et al., 2020). Few research teams have been trying to identify factors linking iron and $\mathrm{O}_{2}$ metabolism. One of these factors is hypoxia-inducible transcription factor (HIF-1) (Romney et al., 2011) that regulates the expression of a vast group of genes under normal $\mathrm{O}_{2}$ conditions $\left(21 \% \mathrm{O}_{2}\right)$ in $C$. elegans, including $\mathrm{ftn}-1$ (Angeles-Albores et al., 2018). Moreover, HIF-1 is responsible for the suppression of $f t n-1$ and $f t n-2$ expression under normal environmental conditions (normoxia - 21\% $\mathrm{O}_{2}$ ) (Ackerman and Gems, 2012; Romney et al., 2011). Additionally, HIF-1 exists in two forms - hydroxylated and non-hydroxylated, and the mechanism of $f t n-1$ expression regulation depends on these forms (Angeles-Albores et al., 2018). The hydroxylated form of HIF- 1 inhibits $f t n-1$ expression under normoxia (Angeles-Albores et al., 2018; Romero-Afrima et al., 2020).

Relating the above reports based on nematode studies to mammals, HIFs were shown to bind to iron regulatory proteins such as transferrin receptors (TfRs) under hypoxia induced by inflammatory diseases or tumors. Additionally, iron plays a role as a cofactor in HIFprolyl hydroxylases (HPHs) responsible for hydroxylation of the HIF-1 regulatory subunit (Strowitzki et al., 2019). The HIF subfamily consists of only one member in C. elegans and four members in mammals (Fong and Takeda, 2008). Interestingly, the upregulation of $f t n-1$ in C. elegans seems to be HIF-1-independent in hypoxia (Romero-Afrima et al. 2020). Additionally, the expression level of $f t n-1$ in the intestine is regulated by specific neurons (AQR, URX, and $\mathrm{PQR}$ ), which use neuropeptide and neurotransmitter signaling that results in decrease in the ftn- 1 expression level at $21 \% \mathrm{O}_{2}$, whereas this effect diminishes at $1 \% \mathrm{O}_{2}$ (Romero-Afrima et al., 2020).

In general, the role of iron management is to minimize the pool of excessive redox-active free iron that triggers free radicals. Because of the ferroxidase activity of FTH and mitochondrial ferritin (FTMT), ferric hydroxides $\left(\mathrm{Fe}^{3+}\right)$ can be stored in mammalian cells of various origin instead of reactive ferrous iron $\left(\mathrm{Fe}^{2+}\right)$ (Hilton et al., 2012; Mesquita et al., 2020). FTMT expression related to iron transfer from the cytosol to the mitochondria is dependent on the HIF protein $(\mathrm{Wu}$ et al., 2019). FTMT in human macrophages prevents cell death induced by iron at reduced $\mathrm{O}_{2}$ levels (in the process called ferroptosis) by decreasing the expression level of nuclear receptor coactivator 4 (NCOA4) (Fuhrmann et al., 2020). NCOA4 serves as a master regulator 
of ferritinophagy (a process by which iron is released from ferritins) as well as a protector against ROS, which was evidenced in hypoxic human macrophages and neuroblastoma cells (Fuhrmann et al., 2020; Wang et al., 2016). Moreover, in mouse fibroblasts and hepatic cells under chemopreventive-induced oxidative stress, nuclear factor E2-related factor 2 (Nrf-2) promotes the expression of both FTL and FTH (Pietsch et al., 2003). Iron is released from ferritin through ferritinophagy followed by binding of the NCOA4 protein to FTH and transfer of the complex for degradation in the autolysosome (Ryu et al., 2018). This further enables the involvement of the released iron in other biosynthetic pathways.

The role of ferritin in cell protection against oxidative stress generated by the imbalance of iron homeostasis is not only associated with hypoxic conditions, but its deregulation may also have a tumor-promoting effect. In C. elegans, the ATPase family AAA domain-containing protein (ATAD-3), a mitochondrial inner membrane protein (Da Cruz et al., 2003) overexpressed in different types of cancers (Fang et al., 2010; Hubstenberger et al., 2008; Li and Rousseau, 2012), can alter the expression of iron homeostasis. This leads to the disruption of iron metabolism. Lack of the ATAD-3 protein in nematodes entails a significant increase in $t$ tn- 1 mRNA level, while ftn-2 mRNA level is downregulated (van den Ecker et al., 2015). These pieces of evidence suggest that the alteration of ferritin expression induced by ATAD-3 may indirectly contribute to the proliferation of cancer cells (van den Ecker et al., 2015). Interestingly, the overexpression of ATAD proteins in human oligodendroglioma, lung adenocarcinoma, and uterine cervical cell lines is related to tumor chemoresistance by promoting resistance to apoptosis and autophagy (Chen et al., 2011; Fang et al., 2010; Hubstenberger et al., 2008). In mammalian models, ATAD regulation of ferritin has not been revealed.

Similarly, studies on cancer tissues harvested from patients have inferred that disorders in sequestering free iron due to excess of ferritin may promote and maintain tumorigenesis (Brookes et al., 2008; Brown et al., 2020). Overexpression of ferritin (with different ratios of FTH and FTL subunits) was detected in many tumor tissues such as pancreatic cancer (Kalousova et al., 2012), Hodgkin's lymphoma (Fernandez-Alvarez et al., 2015), hepatocellular carcinoma (Bian et al., 2018), glioblastoma (Schonberg et al., 2015), and epi- thelial ovarian tumor (Zhao et al., 2018) as well as in serum, e.g., in head and neck squamous cell carcinoma (Hu et al., 2019), peripheral T-cell lymphoma (Koyama et al., 2017), colorectal cancer (Lee et al., 2016), and ovarian tumor (Zhao et al., 2018). Moreover, cancer cells per se secrete ferritin, specifically tumor-associated macrophages (Alkhateeb and Connor, 2013). The ferritin-rich cells located in the breast tumor stroma are considered to be linked with macrophage infiltration (Hanahan and Coussens, 2012; Jezequel et al., 2012). The abundant serum ferritin normally present in circulation was found to be initially secreted by macrophages in vivo (Cohen et al., 2010). Tumor-associated macrophages (TAMs) are characterized by high ferritin expression level (Cozzi et al., 2003). This implies that they can protect malignant cells from iron-driven damage and promote their survival and proliferation (Alkhateeb and Connor, 2013). Moreover, the released extracellular ferritin of this origin promotes angiogenesis (Coffman et al., 2009) and lymphocyte response suppression (Vanoaica et al., 2014). Inflammatory cytokines such as TNF- $\alpha$ or interleukin- $1 \beta$ (IL-1 $\beta$ ) activate nuclear factor kappa-light-chain-enhancer of activated B cells (NF-kB) signaling pathways that induce expression of both FTH and FTL, leading to its synthesis (Pham et al., 2004). Thus, ferritin may have a second, more damaging, tumor-promoting side. Additionally, in humans, extracellular H-ferritin modulates access to iron and exerts an immunosuppressive effect by binding to peripheral lymphocytes and myeloid cells (Sakamoto et al., 2015). Elevated levels of this protein were detected in the serum of melanoma patients, which were accompanied by an increased quantity of circulating $\mathrm{CD} 4+\mathrm{CD} 25+$ regulatory $\mathrm{T}$ cells, thus inducing the suppression of immune responses (Gray, Arosio and Hersey, 2003). A similar irondependent immunosuppressive effect was observed during myelopoiesis - the number of hematopoietic progenitor cells was reduced after recombinant $\mathrm{H}$-ferritin injection to mouse femoral marrow and spleen (Vanoaica et al., 2014).

\section{Ferritin-mediated aging control}

The imbalance of iron metabolism is suggested to affect aging through the activation of ROS generation. The reason why and how we age has not been fully understood. However, there are few theories explaining the senescence. Based on one theory, the constant ge- 
neration of ROS caused by elevated levels of free iron may lead to the accumulation of damage in biomolecules (nucleic acids, lipids in membranes, enzymes, etc.) and eventually cause aging (Kirkwood and Kowald, 2012), which was postulated based on rodent research on food restriction and age-related brain damage (Speakman and Selman, 2011). However, research using C. elegans, which is a model organism to study the effect of ROS on aging, brought difficulties in confirming this theory. It was reported that the lifespan of mutants lacking superoxide dismutase (SOD) isoforms, essential antioxidant enzymes, was not affected. Only sod-1 mutant exhibited a modestly shortened lifespan, and the strain with sod-1 overexpression lived slightly longer. This suggests only a modest contribution of ROS to aging (Doonan et al., 2008).

Nevertheless, excess iron shortens the lifespan of C. elegans (Gourley et al., 2003; Valentini et al., 2012). The excess level of free iron administered as ferric ammonium citrate (FAC) causes protein oxidation, ROS generation, and lifespan shortening but only under the condition where the FAC concentration is above a certain threshold. Interestingly, below this threshold, the lifespan is not disrupted. Thus, under standard conditions, free iron level (not administered as FAC) is not associated with aging (Valentini et al., 2012). Additionally, it was speculated that a high concentration of free radicals may cause failure of antioxidant defense, which eventually leads to cell damage and death (Gourley et al., 2003).

In $C$. elegans, the lack of the abnormal dauer formation gene (daf-2-an ortholog to insulin-like growth factor 1 (IGF-1) encoding the insulin receptor homolog essential for insulin-like signaling (IIS) leads to the extended lifespan (Kimura et al., 1997). Normally, DAF-2 is activated by binding of the insulin-like ligand, which initiates a downstream kinase cascade in IIS (Kimura et al., 1997). However, the daf-2 mutation was linked not only to the extended lifespan but also to increased fat accumulation, developmental delay, increased resistance to a variety of stresses, and reduced brood size (Dorman et al., 1995; Kenyon et al., 1993; Kimura et al., 1997; McElwee et al., 2007; Murphy and Hu, 2013). Moreover, it is worth emphasizing that the daf-2 mutation results in increased $f t n-1$ expression level, which may suggest an indirect involvement of ferritin/iron metabolism in aging (Ackerman and Gems, 2012).
As mentioned above, ferritin as an iron storage protein is responsible for free iron chelation and possesses antioxidant properties that prevent Fenton reaction and subsequent generation of oxidative stress (Levi and Arosio, 2004; Theil, 2010). Additionally, it induces lipid peroxidation, DNA breakage, and other cellular damages. The extended lifespan of daf-2 mutant might be caused by the activation of ferritin-mediated antioxidant defense. It was shown that under normal environmental conditions, the elevated level of free iron leads to the increase in $f t n-1$ expression and activation of ROS production. However, the lifespan of $C$. elegans was not changed (Valentini et al., 2012). Despite these results, the loss of $f t n-1$ (induced by RNAi (RNA interference) or creation of double mutant daf-2;ftn-1) is clearly responsible for the daf-2 mutant resistance to oxidative stress (Valentini et al., 2012). In contrast, studies conducted on the long-lived electron transport chain (ETC) mutant of iron-sulfur protein (ISP-1 - an ortholog of Cytochrome bc1 complex subunit Rieske) revealed a specific role of $C$. elegans P-53-like protein (CEP-1 - an ortholog of p53) in the activation of $f t n-1$ that leads to the lifespan extension of the isp-1 mutant. Interestingly, the expression level of ftn-2 was not changed as compared to that of the control. Nevertheless, in another ETC mutant strain lacking abnormal Methyl viologen sensitivity protein (MEV-1 - an ortholog of succinate dehydrogenase complex subunit $\mathrm{C}$ ), the elevated $\mathrm{ftn}-1$ expression level did not extend the lifespan (Baruah et al., 2014). Hence, the role of ferritin has not been precisely described in the aspect of aging in the nematode model yet.

Studies using other model organisms have also not found a scientific consensus on the precisely defined contribution of ferritin for ageing. Timmers et al. (2020) analyzed genome-wide association studies (GWAS) statistics for health span, parental lifespan, and longevity (taken as a survival to an age above the $90^{\text {th }}$ percentile) in a multivariate approach combining the expression of specific genes in 7350 biological pathways. Pathways associated with heme metabolism proved to be the most relevant contributors to the human intrinsic aging process. As heme synthesis declines with age, its deficiency leads to iron accumulation, thereby causing mitochondrial dysfunction and oxidative stress and sustaining pathogenic infection (Cassat and Skaar, 2013). Observational studies revealed an association of elevated plasma ferritin concentration (a measure of iron accumulation) 
with premature mortality (Ellervik et al., 2014), which may be due to more frequent systemic inflammation, liver diseases, or osteoarthritis (Moen et al., 2018; Pilling et al., 2019). In addition, iron homeostasis impairment in the brain leads to neurodegenerative life-shortening diseases such as multiple sclerosis, Parkinson's disease or Alzheimer's disease as evidenced by magnetic resonance imaging (MRI) of patients' brains (Ward et al., 2014).

Transferrin may reduce oxidative stress and inhibit apoptosis and DNA damage by regulating serum iron concentration (Bogdan et al., 2016; Fassl et al., 2003; Kawabata, 2019). Ferritin plays a similar role by neutralizing the excess ions of this element. In addition, the FOXO3 gene became prominent as being associated with age-related diseases, including detoxification of ROS and affecting survival under dietary restriction in multiple human cohorts (Kenyon, 2010). It was reported that FOXO3a activation leads to the upregulation of ferritin and iron accumulation in the skeletal muscle of amyotrophic lateral sclerosis (ALS) animals (HalonGolabek et al., 2018). However, there is still no solid evidence for the importance of such life-extending variants of genes such as FOXO3a. Its altered expression was observed in elderly patients suffering from specific diseases, which impeded the accurate determination of the effects of individual genes and signaling pathways. Despite the many protective functions of the FOXO3a protein, its expression in the whole blood decreases with age (Sanese et al., 2019; Timmers et al., 2020).

\section{Ferritin as a protector against pathogens}

C. elegans ferritin plays an essential role in the innate immune response against a specific Escherichia coli strain LF82 (isolated from a biopsy sample from a patient with Crohn's disease) and Staphylococcus aureus (Simonsen et al., 2011). Interestingly, FTN-1 was not identified in this study. Only FTN-2 was identified in the mass spectrometry experiment using worms treated with pathogens. The ftn-2 mRNA was significantly upregulated $24 \mathrm{~h}$ post-infection with LF82. The ftn-2 mutant exposed to infection with $E$. coli LF82 or $S$. aureus showed a shortened lifespan as compared to the control when challenged with $E$. coli OP50. However, the lifespan of the ftn-2 mutant and wild-type worms was similar following infection with the OP50 strain (Simonsen et al., 2011).

In mammals, macrophages are the linking elements between the immune system and iron metabolism.
These cells play a core role in both recycling senescent red blood cells and erythropoiesis. Moreover, they are highly involved in iron fluxes in the body (Klei et al., 2017). As already stated, FTH influences macrophage function to counteract ROS-induced oxidative stress and cell death (Mesquita et al., 2020). Simultaneously, the main function of macrophages, as a part of the innate immune system, was shown to be protection against pathogens (Silva-Gomes et al., 2013; Soares and Hamza, 2016). The level of FTH was increased in immune cells following the response to bacterial and viral infection (after the addition of lipopolysaccharide (LPS) or interferon $\gamma$ (IFN- $\gamma$ ) under the experimental conditions), which contributed to the activation of mouse macrophages (Silva-Gomes et al., 2013). Moreover, Fth1 ${ }^{-} /$ primary mouse macrophages were more sensitive to oxidative stress in response to the same treatment.

Recently, the mechanistic target of rapamycin (mTOR) pathway has been described as a regulator of autophagy and ferritin activation (Ma et al., 2021). The correlation between these processes was observed in $C$. elegans following external iron supply and simultaneous infection with pathogens. Under standard cultivation conditions, autophagy was induced by the inhibition of the mTOR signaling pathway following infection with Salmonella enterica serovar typhimurium. However, when external iron was administered, the mTOR pathway was activated and autophagy was inhibited, which subsequently led to the activation of ferritin protein production. The increased level of ferritin protein resulted in the resistance of C. elegans to infection with $S$. typhimurium. FTN-1 and FTN-2 were demonstrated to be important for defense against pathogen infection, but only when worms were exposed to exogenous iron. In the described conditions, ferritin was responsible for limiting the accessibility of iron used by pathogens for growth (Ma et al., 2021).

The mTOR signaling has been identified as a key element in regulating cellular iron transport and in protecting cells from ferroptosis (Yi et al., 2020). Although mTOR-overexpressing mice did not show alleviated ferritin level within the heart area, the homeostasis of cellular iron was sustained by upregulation of different ironbinding proteins, e.g., ferroportin and transferrin receptor 1 (Guan and Wang, 2014). Moreover, the administration of rapamycin, which inhibits the mTOR kinase activity, did not affect ferritin expression. It was postulated that its presence in macrophages lowers trans- 
ferrin receptor 1 (TfR1) levels and may also reduce the iron-stimulatory effect of ferritin expression, thereby making it metabolically available in higher quantity. Collectively, the activity of the mTOR kinase itself promotes cellular iron accumulation (Telser et al., 2019).

Interestingly, it was observed in C. elegans that under stress conditions such as hypoxia, the upregulated FTN-1 level plays an important role in protection against pathogenic bacteria, e.g., Pseudomonas aeruginosa (PA14). Thus, FTN-1 overexpression may be responsible for the increase in worm resistance to pathogens under abnormal environmental conditions (Ma et al., 2021; Romero-Afrima et al., 2020).

\section{Ferritin-associated obesity}

Iron overload present in the human body can be monitored by assessing ferritin level (Zimmermann, 2008). Interestingly, this phenomenon was also described in the aspect of obesity and obesity-related disorders (Iwasaki et al., 2005). Although there are still many unanswered questions, research using $C$. elegans shed a light on the link between iron and lipid metabolism in a more detailed manner. It was demonstrated that the increased level of exogenous iron activates a specific serum- and glucocorticoid-inducible kinase (SGK-1) which induces $\mathrm{ftn-1}$ expression and promotes fat accumulation (Wang et al., 2016a).

Similar interrelationships seem to modulate fat metabolism in adult humans, e.g., hyperferritinemia was diagnosed in individuals with type 2 diabetes mellitus (T2D), metabolic syndrome, or non-alcoholic fatty liver disease (NAFLD), which was recently confirmed in male adolescent patients (Morwald et al., 2020). Dysmetabolic iron overload syndrome (DIOS) coalesces with adult NAFLD, which is manifested by increased serum ferritin levels (Zelber-Sagi et al., 2007). Multivariate analysis conducted on male juveniles with obesity identified liver fat content (LFC, examined by MRI scans) and reactive metabolic inflammation (evidenced by high-sensitive C-reactive protein, $\mathrm{CRP}$ ) as the main determinants of ferritin increase in serum that was independent of the body iron store (Morwald et al., 2020). Moreover, it appears to be a useful marker of early phases of NAFLD development in childhood body fatness in adolescent males rather than in young females due to menstrual blood loss (Du et al., 2017).

\section{Conclusions}

Studies discussed in this review indicate that the mechanism of strict control of iron metabolism is a fundamental component of animal physiology. This is reflected in the preserved evolutionary resemblance in the structure and function of various forms of ferritin proteins in lower (nematodes) and higher (mammals) organisms. Dysregulation of ferritins' levels and activity disturbs the iron storage function, which can have negative effects ranging from free iron deficiency to overload. Examining the influence of ferritin in various model organisms identified its major role as an antioxidant neutralizing ROS generated by toxic ferrous ions. This antioxidant property is achieved using a specific ironbinding ferroxidase center. The complex network of ferritin's intracellular interactions prompts many researchers to investigate its contribution in important processes such as cancerogenesis, obesity, fight against pathogens, or inhibiting of aging in order to develop more effective therapies and improve diagnosis of diseases for the benefit of humans.

\section{References}

Ackerman D., Gems D. (2012) Insulin/igf-1 and hypoxia signaling act in concert to regulate iron homeostasis in Caenorhabditis elegans. PLoS Genet. 8(3): e1002498. http:// doi.org/10.1371/journal.pgen.1002498

Ahmad S., Moriconi F., Naz N., Sultan S., Sheikh N., Ramadori G., Malik I.A. (2013) Ferritin l and ferritin h are differentially located within hepatic and extra hepatic organs under physiological and acute phase conditions. Int. J. Clin. Exp. Pathol. 6(4): 622-629.

Alkhateeb A.A., Connor J.R. (2010) Nuclear ferritin: A new role for ferritin in cell biology. Biochim. Biophys. Acta 1800(8): 793-797. http://doi.org/10.1016/j.bbagen.2010. 03.017

Alkhateeb A.A., Connor J.R. (2013) The significance of ferritin in cancer: Anti-oxidation, inflammation and tumorigenesis. Biochim. Biophys. Acta 1836(2): 245-254. http://doi.org/ 10.1016/j.bbcan.2013.07.002

Anderson C.P., Leibold E.A. (2014) Mechanisms of iron metabolism in caenorhabditis elegans. Front. Pharmacol. 5: 113. http://doi.org/10.3389/fphar.2014.00113

Andrews S.C. (2010) The ferritin-like superfamily: evolution of the biological iron storeman from a rubrerythrin-like ancestor. Biochim. Biophys. Acta 1800(8): 691-705. http:// doi.org/10.1016/j.bbagen.2010.05.010

Angeles-Albores D., Puckett Robinson C., Williams B.A., Wold B.J., Sternberg P.W. (2018) Reconstructing a metazoan 
genetic pathway with transcriptome-wide epistasis measurements. Proc. Natl Acad. Sci. USA 115(13): E2930-E2939. http://doi.org/10.1073/pnas.1712387115

Ayton S., Faux N.G., Bush A.I., Alzheimer's Disease Neuroimaging I. (2015) Ferritin levels in the cerebrospinal fluid predict alzheimer's disease outcomes and are regulated by apoe. Nat. Commun. 6: 6760. http://doi.org/10.1038/ ncomms7760

Balla J., Vercellotti G.M., Nath K., Yachie A., Nagy E., Eaton J.W., Balla G. (2003) Haem, haem oxygenase and ferritin in vascular endothelial cell injury. Nephrol. Dial. Transplant. 18(suppl 5): v8-12. http://doi.org/10.1093/ndt/ gfg1034

Baruah A., Chang H., Hall M., Yuan J., Gordon S., Johnson E., Shtessel L.L., Yee C., Hekimi S., Derry W.B. et al. (2014) Cep-1, the caenorhabditis elegans p53 homolog, mediates opposing longevity outcomes in mitochondrial electron transport chain mutants. PLoS Genet. 10(2): e1004097. http://doi.org/10.1371/journal.pgen.1004097

Bian Z., Hann H.W., Ye Z., Yin C., Wang Y., Fang W., Wan S., Wang C., Tao K. (2018) Ferritin level prospectively predicts hepatocarcinogenesis in patients with chronic hepatitis $b$ virus infection. Oncol. Lett. 16(3): 3499-3508. http://doi.org/10.3892/ol.2018.9099

Bogdan A.R., Miyazawa M., Hashimoto K., Tsuji Y. (2016) Regulators of iron homeostasis: new players in metabolism, cell death, and disease. Trends Biochem. Sci. 41(3): 274-286. http://doi.org/10.1016/j.tibs.2015.11.012

Bou-Abdallah F., Yang H., Awomolo A., Cooper B., Woodhall M.R., Andrews S.C., Chasteen N.D. (2014) Functionality of the three-site ferroxidase center of escherichia coli bacterial ferritin (ecftna). Biochemistry 53(3): 483-495. http://doi.org/10.1021/bi401517f

Bou-Abdallah F., Zhao G., Biasiotto G., Poli M., Arosio P., Chasteen N.D. (2008) Facilitated diffusion of iron(ii) and dioxygen substrates into human h-chain ferritin. A fluorescence and absorbance study employing the ferroxidase center substitution y34w. J. Am. Chem. Soc. 130(52): 17801-17811. http://doi.org/10.1021/ja8054035

Bradley J.M., Moore G.R., Le Brun N.E. (2014) Mechanisms of iron mineralization in ferritins: one size does not fit all. J. Biol. Inorg. Chem. 19(6): 775-785. http://doi.org/ 10.1007/s00775-014-1136-3

Bradley J.M., Svistunenko D.A., Wilson M.T., Hemmings A.M., Moore G.R., Le Brun N.E. (2020) Bacterial iron detoxification at the molecular level. J. Biol. Chem. 295(51): 17602-17623. http://doi.org/10.1074/jbc.REV120.007746

Brookes M.J., Boult J., Roberts K., Cooper B.T., Hotchin N.A., Matthews G., Iqbal T., Tselepis C. (2008) A role for iron in wht signalling. Oncogene 27(7): 966-975. http:// doi.org/10.1038/sj.onc.1210711

Brown R.A.M., Richardson K.L., Kabir T.D., Trinder D., Ganss R., Leedman P.J. (2020) Altered iron metabolism and impact in cancer biology, metastasis, and immunology. Front Oncol. 10: 476. http://doi.org/10.3389/fonc.2020. 00476
Buranrat B., Connor J.R. (2015) Cytoprotective effects of ferritin on doxorubicin-induced breast cancer cell death. Oncol. Rep. 34(5): 2790-2796. http://doi.org/10.3892/ or. 2015.4250

Calhoun L.N., Kwon Y.M. (2011) The ferritin-like protein dps protects salmonella enterica serotype enteritidis from the fenton-mediated killing mechanism of bactericidal antibiotics. Int. J. Antimicrob. Agents 37(3): 261-265. http://doi.org/10.1016/j.ijantimicag.2010.11.034

Cassat J.E., Skaar E.P. (2013) Iron in infection and immunity. Cell Host. Microbe. 13(5): 509-519. http://doi.org/ 10.1016/j.chom.2013.04.010

Celma Nos F., Hernandez G., Ferrer-Cortes X., HernandezRodriguez I., Navarro-Almenzar B., Fuster J.L., Bermudez Cortes M., Perez-Montero S., Tornador C., Sanchez M. (2021) Hereditary hyperferritinemia cataract syndrome: Ferritin 1 gene and physiopathology behind the diseasereport of new cases. Int. J. Mol. Sci. 22(11): 5451. http:// doi.org/10.3390/ijms22115451

Cha'on U., Valmas N., Collins P.J., Reilly P.E., Hammock B.D., Ebert P.R. (2007) Disruption of iron homeostasis increases phosphine toxicity in caenorhabditis elegans. Toxicol. Sci. 96(1): 194-201. http://doi.org/10.1093/toxsci/kfl187

Chakraborti S., Chakrabarti P. (2019) Self-assembly of ferritin: Structure, biological function and potential applications in nanotechnology. Adv. Exp. Med. Biol. 1174: 313-329. http://doi.org/10.1007/978-981-13-9791-2_10

Chen T.C., Hung Y.C., Lin T.Y., Chang H.W., Chiang I.P., Chen Y.Y., Chow K.C. (2011) Human papillomavirus infection and expression of atpase family aaa domain containing 3a, a novel anti-autophagy factor, in uterine cervical cancer. Int. J. Mol. Med. 28(5): 689-696. http://doi.org/ 10.3892/ijmm.2011.743

Chiou B., Connor J.R. (2018) Emerging and dynamic biomedical uses of ferritin. Pharmaceuticals (Basel) 11(4): 124. http://doi.org/10.3390/ph11040124

Coffman L.G., Parsonage D., D'Agostino R., Jr., Torti F.M., Torti S.V. (2009) Regulatory effects of ferritin on angiogenesis. Proc. Natl Acad. Sci. USA 106(2): 570-575. http://doi.org/10.1073/pnas.0812010106

Cohen L.A., Gutierrez L., Weiss A., Leichtmann-Bardoogo Y., Zhang D.L., Crooks D.R., Sougrat R., Morgenstern A., Galy B., Hentze M.W. et al. (2010) Serum ferritin is derived primarily from macrophages through a nonclassical secretory pathway. Blood 116(9): 1574-1584. http:// doi.org/10.1182/blood-2009-11-253815

Cozzi A., Levi S., Corsi B., Santambrogio P., Campanella A., Gerardi G., Arosio P. (2003) Role of iron and ferritin in tnfalpha-induced apoptosis in hela cells. FEBS Lett. 537(1-3): 187-192. http://doi.org/10.1016/s0014-5793(03)00114-5

Crichton R.R., Dexter D.T., Ward R.J. (2011) Brain iron metabolism and its perturbation in neurological diseases. J. Neural. Transm. (Vienna) 118(3): 301-314. http:// doi.org/10.1007/s00702-010-0470-Z

Da Cruz S., Xenarios I., Langridge J., Vilbois F., Parone P.A., Martinou J.C. (2003) Proteomic analysis of the mouse liver 
mitochondrial inner membrane. J. Biol. Chem. 278(42):

41566-41571. http://doi.org/10.1074/jbc.M304940200

Daru J., Colman K., Stanworth S.J., De La Salle B., Wood E.M., Pasricha S.R. (2017) Serum ferritin as an indicator of iron status: what do we need to know? Am. J. Clin. Nutr. 106(suppl 6): 1634S-1639S. http://doi.org/10.3945/ajcn. 117.155960

de Llanos R., Martinez-Garay C.A., Fita-Torro J., Romero A.M., Martinez-Pastor M.T., Puig S. (2016) Soybean ferritin expression in saccharomyces cerevisiae modulates iron accumulation and resistance to elevated iron concentrations. Appl. Environ. Microbiol. 82(10): 3052-3060. http://doi.org/10.1128/AEM.00305-16

Dev S., Babitt J.L. (2017) Overview of iron metabolism in health and disease. Hemodial. Int. 21(suppl. 1): S6-S20. http://doi.org/10.1111/hdi.12542

Doonan R., McElwee J.J., Matthijssens F., Walker G.A., Houthoofd K., Back P., Matscheski A., Vanfleteren J.R., Gems D. (2008) Against the oxidative damage theory of aging: superoxide dismutases protect against oxidative stress but have little or no effect on life span in Caenorhabditis elegans. Genes Dev. 22(23): 3236-3241. http://doi.org/ $10.1101 /$ gad. 504808

Dorman J.B., Albinder B., Shroyer T., Kenyon C. (1995) The age-1 and daf-2 genes function in a common pathway to control the lifespan of caenorhabditis elegans. Genetics 141(4): 1399-1406. http://doi.org/10.1093/genetics/ 141.4.1399

Du S.X., Lu L.L., Geng N., Victor D.W., Chen L.Z., Wang C., Yue H.Y., Xin Y.N., Xuan S.Y., Jin W.W. (2017) Association of serum ferritin with non-alcoholic fatty liver disease: a meta-analysis. Lipids Health Dis. 16(1): 228. http:// doi.org/10.1186/s12944-017-0613-4

Ebrahimi K.H., Hagedoorn P.L., van der Weel L., Verhaert P.D., Hagen W.R. (2012) A novel mechanism of iron-core formation by pyrococcus furiosus archaeoferritin, a member of an uncharacterized branch of the ferritin-like superfamily. J. Biol. Inorg. Chem. 17(6): 975-985. http:// doi.org/10.1007/s00775-012-0913-0

Ellervik C., Marott J.L., Tybjaerg-Hansen A., Schnohr P., Nordestgaard B.G. (2014) Total and cause-specific mortality by moderately and markedly increased ferritin concentrations: general population study and metaanalysis. Clin. Chem. 60(11): 1419-1428. http://doi.org/10.1373/ clinchem.2014.229013

Fang H.Y., Chang C.L., Hsu S.H., Huang C.Y., Chiang S.F., Chiou S.H., Huang C.H., Hsiao Y.T., Lin T.Y., Chiang I.P. et al. (2010) Atpase family aaa domain-containing $3 a$ is a novel anti-apoptotic factor in lung adenocarcinoma cells. J. Cell Sci. 123(7): 1171-1180. http://doi.org/10.1242/ jcs.062034

Fassl S., Leisser C., Huettenbrenner S., Maier S., Rosenberger G., Strasser S., Grusch M., Fuhrmann G., Leuhuber K., Polgar D. et al. (2003) Transferrin ensures survival of ovarian carcinoma cells when apoptosis is induced by tnfalpha, fasl, trail, or myc. Oncogene 22(51): 8343-8355. http://doi.org/10.1038/sj.onc.1207047
Fernandez-Alvarez R., Gonzalez-Rodriguez A.P., Gonzalez M.E., Rubio-Castro A., Dominguez-Iglesias F., Solano J., Alonso-Nogues E., Fernandez-Alvarez C., Zanabili Y., Alonso J.M. et al. (2015) Serum ferritin as prognostic marker in classical hodgkin lymphoma treated with abvd-based therapy. Leuk. Lymphoma 56(11): 3096-3102. http:// doi.org/10.3109/10428194.2015.1038709

Ferreira C., Bucchini D., Martin M.E., Levi S., Arosio P., Grandchamp B., Beaumont C. (2000) Early embryonic lethality of $h$ ferritin gene deletion in mice. J. Biol. Chem. 275(5): 3021-3024. http://doi.org/10.1074/jbc.275.5.3021

Fong G.H., Takeda K. (2008) Role and regulation of prolyl hydroxylase domain proteins. Cell Death Differ. 15(4): 635-641. http://doi.org/10.1038/cdd.2008.10

Fuhrmann D.C., Mondorf A., Beifuss J., Jung M., Brune B. (2020) Hypoxia inhibits ferritinophagy, increases mitochondrial ferritin, and protects from ferroptosis. Redox Biol. 36: 101670. http://doi.org/10.1016/j.redox.2020. 101670

Gao J., Zhou Q., Wu D., Chen L. (2021) Mitochondrial iron metabolism and its role in diseases. Clin. Chim. Acta 513: 6-12. http://doi.org/10.1016/j.cca.2020.12.005

Gourley B.L., Parker S.B., Jones B.J., Zumbrennen K.B., Leibold E.A. (2003) Cytosolic aconitase and ferritin are regulated by iron in caenorhabditis elegans. J. Biol. Chem. 278(5): 3227-3234. http://doi.org/10.1074/jbc.M210333 200

Gray C.P., Arosio P., Hersey P. (2003) Association of increased levels of heavy-chain ferritin with increased cd4t+ cd25+ regulatory t-cell levels in patients with melanoma. Clin. Cancer Res. 9(7): 2551-2559.

Guan P., Wang N. (2014) Mammalian target of rapamycin coordinates iron metabolism with iron-sulfur cluster assembly enzyme and tristetraprolin. Nutrition 30(9): 968-974. http://doi.org/10.1016/j.nut.2013.12.016

Haikarainen T., Papageorgiou A.C. (2010) Dps-like proteins: Structural and functional insights into a versatile protein family. Cell Mol. Life Sci. 67(3): 341-351. http://doi.org/ 10.1007/s00018-009-0168-2

Halon-Golabek M., Borkowska A., Kaczor J.J., Ziolkowski W., Flis D.J., Knap N., Kasperuk K., Antosiewicz J. (2018) Hmsod1 gene mutation-induced disturbance in iron metabolism is mediated by impairment of akt signalling pathway. J. Cachexia Sarcopenia Muscle 9(3): 557-569. http:// doi.org/10.1002/jcsm.12283

Hanahan D., Coussens L.M. (2012) Accessories to the crime: functions of cells recruited to the tumor microenvironment. Cancer Cell. 21(3): 309-322. http://doi.org/ 10.1016/j.ccr.2012.02.022

He L., He T., Farrar S., Ji L., Liu T., Ma X. (2017) Antioxidants maintain cellular redox homeostasis by elimination of reactive oxygen species. Cell Physiol. Biochem. 44(2): 532-553. http://doi.org/10.1159/000485089

Hilton R.J., David Andros N., Watt R.K. (2012) The ferroxidase center is essential for ferritin iron loading in the presence of phosphate and minimizes side reactions that 
form fe(iii)-phosphate colloids. Biometals. 25(2): 259-273. http://doi.org/10.1007/s10534-011-9500-z

Hintze K.J., Theil E.C. (2006) Cellular regulation and molecular interactions of the ferritins. Cell Mol. Life Sci. 63(5): 591-600. http://doi.org/10.1007/s00018-005-5285-y

Hohaus S., Giachelia M., Cuccaro A., Voso M.T., Leone G. (2013) Iron in hodgkin's lymphoma. Crit. Rev. Oncog. 18(5): 463-469. http://doi.org/10.1615/critrevoncog. 2013007765

Honarmand Ebrahimi K., Bill E., Hagedoorn P.L., Hagen W.R. (2012) The catalytic center of ferritin regulates iron storage via fe(ii)-fe(iii) displacement. Nat. Chem. Biol. 8(11): 941-948. http://doi.org/10.1038/nchembio.1071

Hu Z., Wang L., Han Y., Li F., Zheng A., Xu Y., Wang F., Xiao B., Chen C., Tao Z. (2019) Ferritin: a potential serum marker for lymph node metastasis in head and neck squamous cell carcinoma. Oncol. Lett. 17(1): 314-322. http:// doi.org/10.3892/ol.2018.9642

Hubstenberger A., Labourdette G., Baudier J., Rousseau D. (2008) Atad 3a and atad $3 b$ are distal 1p-located genes differentially expressed in human glioma cell lines and present in vitro anti-oncogenic and chemoresistant properties. Exp. Cell Res. 314(15): 2870-2883. http://doi.org/ 10.1016/j.yexcr.2008.06.017

Iwasaki T., Nakajima A., Yoneda M., Yamada Y., Mukasa K., Fujita K., Fujisawa N., Wada K., Terauchi Y. (2005) Serum ferritin is associated with visceral fat area and subcutaneous fat area. Diabetes Care 28(10): 2486-2491. http:// doi.org/10.2337/diacare.28.10.2486

James S.A., Roberts B.R., Hare D.J., de Jonge M.D., Birchall I.E., Jenkins N.L., Cherny R.A., Bush A.I., McColl G. (2015) Direct in vivo imaging of ferrous iron dyshomeostasis in ageing caenorhabditis elegans. Chem. Sci. 6(5): 2952-2962. http://doi.org/10.1039/c5sc00233h

Jezequel P., Campion L., Spyratos F., Loussouarn D., Campone M., Guerin-Charbonnel C., Joalland M.P., Andre J., Descotes F., Grenot C. et al. (2012) Validation of tumorassociated macrophage ferritin light chain as a prognostic biomarker in node-negative breast cancer tumors: a multicentric 2004 national phrc study. Int. J. Cancer 131(2): 426-437. http://doi.org/10.1002/ijc.26397

Jian N., Dowle M., Horniblow R.D., Tselepis C., Palmer R.E. (2016) Morphology of the ferritin iron core by aberration corrected scanning transmission electron microscopy. Nanotechnology 27(46): 46LT02. http://doi.org/10.1088/ 0957-4484/27/46/46LT02

Kalousova M., Krechler T., Jachymova M., Kubena A.A., Zak A., Zima T. (2012) Ferritin as an independent mortality predictor in patients with pancreas cancer. Results of a pilot study. Tumour Biol. 33(5): 1695-1700. http:// doi.org/10.1007/s13277-012-0426-Z

Kawabata H. (2019) Transferrin and transferrin receptors update. Free Radic. Biol. Med. 133: 46-54. http://doi.org/ 10.1016/j.freeradbiomed.2018.06.037

Kelley L.A., Mezulis S., Yates C.M., Wass M.N., Sternberg M.J. (2015) The phyre2 web portal for protein modeling, prediction and analysis. Nat. Protoc. 10(6): 845-858. http://doi.org/10.1038/nprot.2015.053

Kenyon C., Chang J., Gensch E., Rudner A., Tabtiang R. (1993) $A$ C. elegans mutant that lives twice as long as wild type. Nature 366(6454): 461-464. http://doi.org/10.1038/ $366461 \mathrm{a} 0$

Kenyon C.J. (2010) The genetics of ageing. Nature 464(7288): 504-512. http://doi.org/10.1038/nature08980

Kim Y.I., Cho J.H., Yoo O.J., Ahnn J. (2004) Transcriptional regulation and life-span modulation of cytosolic aconitase and ferritin genes in C. elegans. J. Mol. Biol. 342(2): 421-433. http://doi.org/10.1016/j.jmb.2004.07.036

Kimura K.D., Tissenbaum H.A., Liu Y., Ruvkun G. (1997) Daf-2, an insulin receptor-like gene that regulates longevity and diapause in caenorhabditis elegans. Science 277(5328): 942-946. http://doi.org/10.1126/science. 277.5328.942

Kirkwood T.B., Kowald A. (2012) The free-radical theory of ageing-older, wiser and still alive: modelling positional effects of the primary targets of ros reveals new support. Bioessays 34(8): 692-700. http://doi.org/10.1002/bies. 201200014

Klei T.R., Meinderts S.M., van den Berg T.K., van Bruggen R. (2017) From the cradle to the grave: the role of macrophages in erythropoiesis and erythrophagocytosis. Front Immunol. 8: 73. http://doi.org/10.3389/fimmu.2017.00073

Knovich M.A., Storey J.A., Coffman L.G., Torti S.V., Torti F.M. (2009) Ferritin for the clinician. Blood Rev. 23(3): 95-104. http://doi.org/10.1016/j.blre.2008.08.001

Koyama S., Fujisawa S., Watanabe R., Itabashi M., Ishibashi D., Ishii Y., Hattori Y., Nakajima Y., Motohashi K., Takasaki H. et al. (2017) Serum ferritin level is a prognostic marker in patients with peripheral t-cell lymphoma. Int. J. Lab. Hematol. 39(1): 112-117. http://doi.org/10.1111/ ijlh.12592

Laghaei R., Kowallis W., Evans D.G., Coalson R.D. (2014) Calculation of iron transport through human h-chain ferritin. J. Phys. Chem. A. 118(35): 7442-7453. http:// doi.org/10.1021/jp500198u

Larkin M.A., Blackshields G., Brown N.P., Chenna R., McGettigan P.A., McWilliam H., Valentin F., Wallace I.M., Wilm A., Lopez R. et al. (2007) Clustal $w$ and clustal $x$ version 2.0. Bioinformatics 23(21): 2947-2948. http://doi.org/ 10.1093/bioinformatics/btm404

Laufberger V. (1937) Sur la cristallisation de la ferritine. Bull. Soc. Chim. Biol. 19: 1575-1582. http://doi.org/10.1371/ journal.pgen.1002498

Lee S., Song A., Eo W. (2016) Serum ferritin as a prognostic biomarker for survival in relapsed or refractory metastatic colorectal cancer. J. Cancer 7(8): 957-964. http://doi.org/ 10.7150/jca. 14797

Levi S., Arosio P. (2004) Mitochondrial ferritin. Int. J. Biochem. Cell Biol. 36(10): 1887-1889. http://doi.org/ 10.1016/j.biocel.2003.10.020

Levi S., Ripamonti M., Dardi M., Cozzi A., Santambrogio P. (2021) Mitochondrial ferritin: its role in physiological and 
pathological conditions. Cells 10(8): 1969. http://doi.org/ 10.3390/cells10081969

Li S., Rousseau D. (2012) Atad3, a vital membrane bound mitochondrial atpase involved in tumor progression. J. Bioenerg. Biomembr. 44(1): 189-197. http://doi.org/ 10.1007/s10863-012-9424-5

Ma Y.C., Dai L.L., Qiu B.B., Zhou Y., Zhao Y.Q., Ran Y., Zhang K.Q., Zou C.G. (2021) Tor functions as a molecular switch connecting an iron cue with host innate defense against bacterial infection. PLoS Genet. 17(3): e1009383. http:// doi.org/10.1371/journal.pgen.1009383

Masuda T., Goto F., Yoshihara T., Ezure T., Suzuki T., Kobayashi S., Shikata M., Utsumi S. (2007) Construction of homo- and heteropolymers of plant ferritin subunits using an in vitro protein expression system. Protein Exp. Purif. 56(2): 237-246. http://doi.org/10.1016/j.pep.2007.07.011

McElwee J.J., Schuster E., Blanc E., Piper M.D., Thomas J.H., Patel D.S., Selman C., Withers D.J., Thornton J.M., Partridge L. et al. (2007) Evolutionary conservation of regulated longevity assurance mechanisms. Genome Biol. 8(7): R132. http://doi.org/10.1186/gb-2007-8-7-r132

Melman A., Bou-Abdallah F. (2020) Iron mineralization and core dissociation in mammalian homopolymeric h-ferritin: Current understanding and future perspectives. Biochim. Biophys. Acta Gen. Subj. 1864(11): 129700. http:// doi.org/10.1016/j.bbagen.2020.129700

Mesquita G., Silva T., Gomes A.C., Oliveira P.F., Alves M.G., Fernandes R., Almeida A.A., Moreira A.C., Gomes M.S. (2020) H-ferritin is essential for macrophages' capacity to store or detoxify exogenously added iron. Sci. Rep. 10(1): 3061. http://doi.org/10.1038/s41598-020-59898-0

Moen I.W., Bergholdt H.K.M., Mandrup-Poulsen T., Nordestgaard B.G., Ellervik C. (2018) Increased plasma ferritin concentration and low-grade inflammation-a mendelian randomization study. Clin. Chem. 64(2): 374-385. http:// doi.org/10.1373/clinchem.2017.276055

Morwald K., Aigner E., Bergsten P., Brunner S.M., Forslund A., Kullberg J., Ahlstrom H., Manell H., Roomp K., Schutz S. et al. (2020) Serum ferritin correlates with liver fat in male adolescents with obesity. Front. Endocrinol. (Lausanne) 11: 340. http://doi.org/10.3389/fendo.2020.00340

Muhoberac B.B., Vidal R. (2019) Iron, ferritin, hereditary ferritinopathy, and neurodegeneration. Front. Neurosci. 13: 1195. http://doi.org/10.3389/fnins.2019.01195

Mura C.V., Delgado R., Aguirre P., Bacigalupo J., Nunez M.T. (2006) Quiescence induced by iron challenge protects neuroblastoma cells from oxidative stress. J. Neurochem. 98(1): 11-19. http://doi.org/10.1111/j.1471-4159.2006. 03798.x

Murphy C.T., Hu P.J. (2013) Insulin/insulin-like growth factor signaling in C. elegans. WormBook: 1-43. http://doi.org/ 10.1895/wormbook.1.164.1

Naumova A.V., Balu N., Yarnykh V.L., Reinecke H., Murry C.E., Yuan C. (2014) Magnetic resonance imaging tracking of graft survival in the infarcted heart: Iron oxide particles versus ferritin overexpression approach. J. Cardiovasc.
Pharmacol. Ther. 19(4): 358-367. http://doi.org/10.1177/ 1074248414525999

Orino K., Lehman L., Tsuji Y., Ayaki H., Torti S.V., Torti F.M. (2001) Ferritin and the response to oxidative stress. Biochem. J. 357(1): 241-247. http://doi.org/10.1042/02646021:3570241

Pham C.G., Bubici C., Zazzeroni F., Papa S., Jones J., Alvarez K., Jayawardena S., De Smaele E., Cong R., Beaumont C. et al. (2004) Ferritin heavy chain upregulation by nf-kappab inhibits tnfalpha-induced apoptosis by suppressing reactive oxygen species. Cell 119(4): 529-542. http:// doi.org/10.1016/j.cell.2004.10.017

Pietsch E.C., Chan J.Y., Torti F.M., Torti S.V. (2003) Nrf2 mediates the induction of ferritin $h$ in response to xenobiotics and cancer chemopreventive dithiolethiones. J. Biol. Chem. 278(4): 2361-2369. http://doi.org/10.1074/ jbc.M210664200

Pilling L.C., Tamosauskaite J., Jones G., Wood A.R., Jones L., Kuo C.L., Kuchel G.A., Ferrucci L., Melzer D. (2019) Common conditions associated with hereditary haemochromatosis genetic variants: cohort study in uk biobank. BMJ 364: k5222. http://doi.org/10.1136/bmj.k5222

Pozzi C., Di Pisa F., Bernacchioni C., Ciambellotti S., Turano P., Mangani S. (2015) Iron binding to human heavy-chain ferritin. Acta Crystallogr. D: Biol. Crystallogr. 71(9): 1909-1920. http://doi.org/10.1107/S1399004715013073

Pulos-Holmes M.C., Srole D.N., Juarez M.G., Lee A.S., McSwiggen D.T., Ingolia N.T., Cate J.H. (2019) Repression of ferritin light chain translation by human eif3. eLife 8: e48193. http://doi.org/10.7554/eLife.48193

Romero-Afrima L., Zelmanovich V., Abergel Z., Zuckerman B., Shaked M., Abergel R., Livshits L., Smith Y., Gross E. (2020) Ferritin is regulated by a neuro-intestinal axis in the nematode caenorhabditis elegans. Redox Biol. 28: 101359. http://doi.org/10.1016/j.redox.2019.101359

Romney S.J., Newman B.S., Thacker C., Leibold E.A. (2011) Hif-1 regulates iron homeostasis in caenorhabditis elegans by activation and inhibition of genes involved in iron uptake and storage. PLoS Genet. 7(12): e1002394. http:// doi.org/10.1371/journal.pgen.1002394

Romney S.J., Thacker C., Leibold E.A. (2008) An iron enhancer element in the ftn-1 gene directs iron-dependent expression in caenorhabditis elegans intestine. J. Biol. Chem. 283(2): 716-725. http://doi.org/10.1074/jbc.M707043200

Ryu M.S., Duck K.A., Philpott C.C. (2018) Ferritin iron regulators, pcbp1 and ncoa4, respond to cellular iron status in developing red cells. Blood Cells Mol. Dis. 69: 75-81. http://doi.org/10.1016/j.bcmd.2017.09.009

Sakamoto S., Kawabata H., Masuda T., Uchiyama T., Mizumoto C., Ohmori K., Koeffler H.P., Kadowaki N., TakaoriKondo A. (2015) H-ferritin is preferentially incorporated by human erythroid cells through transferrin receptor 1 in a threshold-dependent manner. PLoS One. 10(10): e0139915. http://doi.org/10.1371/journal.pone.0139915

Sanese P., Forte G., Disciglio V., Grossi V., Simone C. (2019) Foxo3 on the road to longevity: Lessons from snps and 
chromatin hubs. Comput. Struct. Biotechnol. J. 17: 737-745. http://doi.org/10.1016/j.csbj.2019.06.011

Schonberg D.L., Miller T.E., Wu Q., Flavahan W.A., Das N.K., Hale J.S., Hubert C.G., Mack S.C., Jarrar A.M., Karl R.T. et al. (2015) Preferential iron trafficking characterizes glioblastoma stem-like cells. Cancer Cell. 28(4): 441-455. http://doi.org/10.1016/j.ccell.2015.09.002

Sievers F., Wilm A., Dineen D., Gibson T.J., Karplus K., Li W., Lopez R., McWilliam H., Remmert M., Soding J. et al. (2011) Fast, scalable generation of high-quality protein multiple sequence alignments using clustal omega. Mol. Syst. Biol. 7: 539. http://doi.org/10.1038/msb.2011.75

Silva-Gomes S., Bouton C., Silva T., Santambrogio P., Rodrigues P., Appelberg R., Gomes M.S. (2013) Mycobacterium avium infection induces $h$-ferritin expression in mouse primary macrophages by activating toll-like receptor 2. PLoS One. 8(12): e82874. http://doi.org/10.1371/journal. pone. 0082874

Simonsen K.T., Moller-Jensen J., Kristensen A.R., Andersen J.S., Riddle D.L., Kallipolitis B.H. (2011) Quantitative proteomics identifies ferritin in the innate immune response of C. elegans. Virulence 2(2): 120-130. http://doi.org/ 10.4161/viru.2.2.15270

Soares M.P., Hamza I. (2016) Macrophages and iron metabolism. Immunity 44(3): 492-504. http://doi.org/10.1016/ j.immuni.2016.02.016

Speakman J.R., Selman C. (2011) The free-radical damage theory: Accumulating evidence against a simple link of oxidative stress to ageing and lifespan. Bioessays 33(4): 255-259. http://doi.org/10.1002/bies.201000132

Strowitzki M.J., Cummins E.P., Taylor C.T. (2019) Protein hydroxylation by hypoxia-inducible factor (hif) hydroxylases: Unique or ubiquitous? Cells 8(5): 384. http://doi.org/ 10.3390/cells 8050384

Tang B., Zhu J., Li J., Fan K., Gao Y., Cheng S., Kong C., Zheng L., Wu F., Weng Q. et al. (2020) The ferroptosis and iron-metabolism signature robustly predicts clinical diagnosis, prognosis and immune microenvironment for hepatocellular carcinoma. Cell Commun. Signal. 18(1): 174. http://doi.org/10.1186/s12964-020-00663-1

Telser J., Volani C., Hilbe R., Seifert M., Brigo N., Paglia G., Weiss G. (2019) Metabolic reprogramming of salmonella infected macrophages and its modulation by iron availability and the mtor pathway. Microb. Cell. 6(12): 531-543. http://doi.org/10.15698/mic2019.12.700

Theil E.C. (2010) Ferritin iron minerals are chelator targets, antioxidants, and coated, dietary iron. Ann. N. Y. Acad. Sci. 1202: 197-204. http://doi.org/10.1111/j.1749-6632. 2010. 05575.x

Thompson K., Menzies S., Muckenthaler M., Torti F.M., Wood T., Torti S.V., Hentze M.W., Beard J., Connor J. (2003) Mouse brains deficient in h-ferritin have normal iron concentration but a protein profile of iron deficiency and increased evidence of oxidative stress. J. Neurosci. Res. 71(1): 46-63. http://doi.org/10.1002/jnr.10463

Timmers P., Wilson J.F., Joshi P.K., Deelen J. (2020) Multivariate genomic scan implicates novel loci and haem meta- bolism in human ageing. Nat. Commun. 11(1): 3570. http://doi.org/10.1038/s41467-020-17312-3

Valentini S., Cabreiro F., Ackerman D., Alam M.M., Kunze M.B., Kay C.W., Gems D. (2012) Manipulation of in vivo iron levels can alter resistance to oxidative stress without affecting ageing in the nematode $C$. elegans. Mech. Ageing Dev. 133(5): 282-290. http://doi.org/10.1016/j.mad.2012. 03.003

van den Ecker D., Hoffmann M., Muting G., Maglioni S., Herebian D., Mayatepek E., Ventura N., Distelmaier F. (2015) Caenorhabditis elegans atad-3 modulates mitochondrial iron and heme homeostasis. Biochem. Biophys. Res. Commun.467(2): 389-394. http://doi.org/10.1016/j.bbrc. 2015. 09.143

Vanoaica L., Richman L., Jaworski M., Darshan D., Luther S.A., Kuhn L.C. (2014) Conditional deletion of ferritin $h$ in mice reduces $b$ and $t$ lymphocyte populations. PLoS One. 9(2): e89270. http://doi.org/10.1371/journal.pone.0089270

Vela D. (2020) Iron in the tumor microenvironment. Adv. Exp. Med. Biol. 1259: 39-51. http://doi.org/10.1007/978-3-03043093-1_3

Wang F., Lv H., Zhao B., Zhou L., Wang S., Luo J., Liu J., Shang P. (2019) Iron and leukemia: New insights for future treatments. J. Exp. Clin. Cancer Res. 38(1): 406. http://doi.org/10.1186/s13046-019-1397-3

Wang Y.Q., Chang S.Y., Wu Q., Gou Y.J., Jia L., Cui Y.M., Yu P., Shi Z.H., Wu W.S., Gao G. et al. (2016) The protective role of mitochondrial ferritin on erastin-induced ferroptosis. Front Aging Neurosci. 8: 308. http://doi.org/ 10.3389/fnagi.2016.00308

Ward R.J., Zucca F.A., Duyn J.H., Crichton R.R., Zecca L. (2014) The role of iron in brain ageing and neurodegenerative disorders. Lancet Neurol. 13(10): 1045-1060. http:// doi.org/ 10.1016/S1474-4422(14)70117-6

Wessling-Resnick M. (2010) Iron homeostasis and the inflammatory response. Annu. Rev. Nutr. 30: 105-122. http:// doi.org/10.1146/annurev.nutr.012809.104804

Wiedenheft B., Mosolf J., Willits D., Yeager M., Dryden K.A., Young M., Douglas T. (2005) An archaeal antioxidant: characterization of a dps-like protein from sulfolobus solfataricus. Proc. Natl Acad. Sci. USA 102(30): 10551-10556. http://doi.org/10.1073/pnas.0501497102

Wu Q., Wu W.S., Su L., Zheng X., Wu W.Y., Santambrogio P., Gou Y.J., Hao Q., Wang P.N., Li Y.R. et al. (2019) Mitochondrial ferritin is a hypoxia-inducible factor 1alpha-inducible gene that protects from hypoxia-induced cell death in brain. Antioxid. Redox Signal. 30(2): 198-212. http:// doi.org/10.1089/ars.2017.7063

Yasmin S., Andrews S.C., Moore G.R., Le Brun N.E. (2011) A new role for heme, facilitating release of iron from the bacterioferritin iron biomineral. J. Biol. Chem. 286(5): 3473-3483. http://doi.org/10.1074/jbc.M110.175034

Yevenes A. (2017) The ferritin superfamily. Subcell Biochem. 83: 75-102. http://doi.org/10.1007/978-3-319-46503-6_3

Yi J., Zhu J., Wu J., Thompson C.B., Jiang X. (2020) Oncogenic activation of pi3k-akt-mtor signaling suppresses ferroptosis 
via srebp-mediated lipogenesis. Proc. Natl Acad. Sci. USA 117(49): 31189-31197. http://doi.org/10.1073/pnas.2017 152117

Zarjou A., Jeney V., Arosio P., Poli M., Zavaczki E., Balla G., Balla J. (2010) Ferritin ferroxidase activity: a potent inhibitor of osteogenesis. J. Bone Miner. Res. 25(1): 164-172. http://doi.org/10.1359/jbmr.091002

Zelber-Sagi S., Nitzan-Kaluski D., Halpern Z., Oren R. (2007) Nafld and hyperinsulinemia are major determinants of serum ferritin levels. J. Hepatol. 46(4): 700-707. http:// doi.org/10.1016/j.jhep.2006.09.018

Zhang K.H., Tian H.Y., Gao X., Lei W.W., Hu Y., Wang D.M., Pan X.C., Yu M.L., Xu G.J., Zhao F.K. et al. (2009) Ferritin heavy chain-mediated iron homeostasis and subsequent increased reactive oxygen species production are essential for epithelial-mesenchymal transition. Cancer Res. 69(13): 5340-5348. http://doi.org/10.1158/0008-5472.CAN-090112

Zhang N., Yu X., Xie J., Xu H. (2021) New insights into the role of ferritin in iron homeostasis and neurodegenerative diseases. Mol. Neurobiol. 58(6): 2812-2823. http:// doi.org/10.1007/s12035-020-02277-7

Zhao G., Bou-Abdallah F., Arosio P., Levi S., Janus-Chandler C., Chasteen N.D. (2003) Multiple pathways for mineral core formation in mammalian apoferritin. The role of hydrogen peroxide. Biochemistry 42(10): 3142-3150. http://doi.org/10.1021/bi027357v

Zhao J., Guo N., Zhang L., Wang L. (2018) Serum ca125 in combination with ferritin improves diagnostic accuracy for epithelial ovarian cancer. Br. J. Biomed. Sci. 75(2): 66-70. http://doi.org/10.1080/09674845.2017.1394051

Zhou Z.D., Tan E.K. (2017) Iron regulatory protein (irp)-iron responsive element (ire) signaling pathway in human neurodegenerative diseases. Mol. Neurodegener. 12(1): 75. http://doi.org/10.1186/s13024-017-0218-4

Zimmermann M.B. (2008) Methods to assess iron and iodine status. Br. J. Nutr. 99(suppl. 3): S2-9. http://doi.org/ 10.1017/S000711450800679X 